\title{
Ecological Footprint at the Micro-Scale-How It Can Save Costs: The Case of ENPRO
}

\author{
Gergely Tóth ${ }^{1, *}$, Cecília Szigeti 2 (1) , Gábor Harangozó ${ }^{3}$ and Dániel Róbert Szabó ${ }^{4}$ \\ 1 Department of Economics and Finance, Faculty of Economic Science, Kaposvár University, \\ 7400 Kaposvár, Hungary \\ 2 Department of International and Theoretical Economics, Kautz Gyula Economics Faculty, \\ Széchenyi István University, 9026 Győr, Hungary; szigetic@sze.hu \\ 3 Department of Logistics and Supply Chain Management, Corvinus Business School, \\ Corvinus University of Budapest, 1093 Budapest, Hungary; gabor.harangozo@uni-corvinus.hu \\ 4 Department of Economic Analysis, Kautz Gyula Economics Faculty, Széchenyi István University, \\ 9026 Győr, Hungary; szabodr@sze.hu \\ * Correspondence: toth.gergely@ke.hu; Tel.: +36-20-522-7897
}

Received: 16 May 2018; Accepted: 29 July 2018; Published: 1 August 2018

\begin{abstract}
The Ecological Footprint (EF) has become a very popular alternative indicator of development in the last three decades. It can be widely used to show the unsustainability of total and individual levels of consumption in countries. But can EF be a meaningful indicator at the micro level as well? This paper presents an argument on this issue. Based on a literature review including our own analysis and the correlation of EF with GDP and other alternative indicators, EF is evaluated at the macro level. Then, an original case study is presented, underpinning the applicability of EF on the company level, linking the ordinary corporate carbon footprinting with the EF method. Based on the findings, micro level EF calculations can help organizations in finding fields of intervention (inefficiencies and emission hotspots). EF accounting can also be used to evaluate the economic benefits of such measures after their realization.
\end{abstract}

Keywords: historical ecological footprint; corporate carbon footprint; human economics; sustainable development; ecological indicators; econometrics

\section{Introduction}

Ecological footprint $(\mathrm{EF})$ has become a popular indicator since its first publication in the 1990s [1,2]. The purpose of this approach is to quantify the size of land (and resources) used by countries (by determining human pressure onto the ecosystem in terms of global hectares, considering also the different productivity of various land types) to satisfy the needs of the population of the country over the course of a year [3]. In this context, it can even be considered as an absolute indicator of sustainability [4], as it can be compared to what is available i.e., the biocapacity (BC, referring to the sum of different land types, weighted by their ecological productivity) of the Earth. Over recent decades, the methodology has evolved and now there are approaches that address the ecological footprint at regional, individual and even organizational level [5], adding new insights to the sustainability discourse. Since Mathis Wackernagel and William Rees published their groundbreaking book [1] proposing EF as an alternative indicator of development (supplementing mainstream ones such as GDP), its popularity keeps on growing. According to the 2016 Living Planet Report [6], mankind's per capita EF is 2.8 global hectares (gha), while the available BC only supports a 1.7 gha per capita footprint, resulting in a $60 \%$ overuse rate. The Earth Overshoot Day, the date when humanity has exhausted nature's budget for the whole year, falls on 1 August 2018. 
The Global Footprint Network (GFN) publishes data only for some decades, and the earliest data is calculated for 1961. Based on analyzing the GFN dataset on country level historical EF, of some 870,000 pieces of data starting from 1961, we found a positive correlation between GDP and EF ([7], in line with $[8,9])$. With the method of backcasting, using historical statistics, we also estimated the historical EF from 10,000 B.C. to present [7]. We also found that at the beginning of the industrial revolution, human EF accounted only for about $5-10 \%$ of $B C$, while since 1970 this figure exceeds $150 \%$. Based on our calculations, the estimated EF varied between 1.2-1.45 global hectares per capita for a very long period before the industrial revolution (lower than the available per capita $B C$, which could be considered as sustainable). A less known fact is that, although the deficit widens, the per capita EF is decreasing slowly, but steadily. It reached its peak in 1973 (2.88 gha), had a local maximum in 1978-1979 (2.83 gha) and has shown a local minimum of 2.45 gha in 2001-2002. Total EF of humanity clearly shows a sigmoid (S) curve: the descending part (slowing acceleration) can be seen in the last three decades [7].

In our previous research [7], we calculated global EF data for the last 12,000 years and harmonized it with the GFN database for the last 50 years. We found that, recently, overconsumption —of at least high-income consumers-became the primary driver of (over)growth and unsustainable development. As the rapid increase of consumption overtook population growth, our first goal for reaching sustainable development is not restricting the birth rates or vital, basic consumption of the poorer part of humanity, mostly living in developing countries, but rather, to voluntarily make temperance (not consuming more, than it is sufficient, even if it would be affordable) a chief virtue again: to level-off the "overconsumption" of the high-income population of developed countries.

In another paper [10] we presented a calculation for the correlation of GDP and four alternatives to GDP indicators. According to our findings, the Happy Planet Index (HPI) and the Environmental Performance Index (EPI) can be considered as independent from GDP (Pearson coefficient -0.189 and 0.484 respectively) and the other two indicators (Human Development Index, HDI, and EF). On the other hand, the HDI and the EF show high correlation with GDP (Pearson coefficient 0.758 and 0.909 respectively). This latter finding supports the idea that economic growth does not (automatically) solve environmental issues (such as considered by advocating of the green growth stream [11-13]. The data suggest the opposite, i.e., that higher levels of GDP and (over)consumption increase pressure on the Earth's ecosystem.

Based on the literature referred to so far, the role of EF seems to be justified at the global and national level. But how can we use the EF on smaller scales? Can it be an indicator to plan a sustainable lifestyle in private life or a sustainability indicator at the corporate level?

The aim of the present study is to point out that EF accounts can be a useful indicator also at the micro level, helping both to evaluate and develop eco-efficiency strategies for companies. For that purpose, we present an original case study on corporate ecological and carbon footprinting, analyzing how information on fuel consumption, energy input etc. can be used for optimal corporate decisions from the perspective of sustainability. We try to link corporate carbon footprinting $[14,15]$ to ecological footprint accounts, in a way that we translate mass units of carbon emissions into land areas of EF. This can serve as a first step for calculating corporate EF. We also discuss the potential extension of the corporate scope on EF calculation.

\section{Conceptual Framework and Methods}

\subsection{Ecological Footprint vs. Carbon Footprint}

As mentioned in the previous section, EF measures how much productive land is needed for a human society to maintain itself and to process its generated waste at a given level of technological development [1,5]. According to the concept, the EF indicator consists of six main categories of land use: cropland, grazing land, forest land (the production of raw materials), fishing grounds, infrastructure (built-in land) and the land area required to absorb carbon-dioxide emissions from the use of fossil 
fuels [3]. Considering the fact that different land types vary in productivity, Equivalence Factors (EQF) are applied, to make these different land types comparable (in gha). The yield factor (YF) aims to provide information on how productive a certain type of land in a certain country is, as compared to the global averages (on EQF and YF see [16]). For calculating the EF of a specific area, we need to weight the resources taken from different land types by respective YFs and EQFs to get the EF in gha.

The Carbon Footprint (CF) can be understood on two levels. First, it focuses on the last of the six land use categories of the EF [1,17]. In this sense, the CF component of the EF methodology measures the bio-productive land needed to sequester the anthropogenic $\mathrm{CO}_{2}$-emissions. Second, $\mathrm{CF}$ is an indicator that measures the quantity of greenhouse gas emissions that are generated in a certain area or linked to a certain activity $[14,15]$, directly or indirectly $[18,19]$. It is also interpreted as a sum of Greenhouse Gases (GHG) being connected to the different lifecycle phases of products based on the Life Cycle Assessment (LCA) approach. From this point of view, corporate level carbon footprints can be defined as the total carbon (or greenhouse gas) emissions related to the activity or products of a certain company [20-23].

The CF concept can cover $\mathrm{CO}_{2}$-emissions only, or may include other GHGs covered by the Kyoto Agreement. In the second case, the denomination of carbon footprint might also be challenged, since non-carbon greenhouse gases are also included. As a solution to this problem, Downie and Stubbs [24] recommend the term greenhouse gas footprint instead. Furthermore, the analysis can be extended to an even broader level — analyzing all of the elements of the corporate level EF (such as the physical infrastructure as a part of the built-in footprint component or agricultural or food products used by or in the company forming the base of the cropland footprint component, etc.), see for example studies [25,26].

In the first interpretation (CF as the carbon uptake land needed to neutralize emissions), $\mathrm{CF}$ is quantified in gha [1,17]. However, in the second approach [14,15], CF can also be measured in mass units (kilograms or tons) of carbon-dioxide [27]. Additionally, as different greenhouse gases have different per unit contribution to climate change (referred as the Global Warming Potential, GWP, where the GWP of carbon-dioxide is taken as 1) carbon-dioxide equivalents can be applied [28], in order to bring different gases to a common denominator. In this case, $\mathrm{CF}$ is calculated as the sum of the emission quantities of different greenhouse gases weighted by the respective GWPs.

\subsection{Corporate Carbon Footprints}

The total carbon footprint of a company should include all the resources, stakeholders, and processes within the entire corporate system (including all other units where carbon emissions can be released as a result of the activity of the specific company) and supply chain following the LCA-approach from raw material extraction, transportation, production and processes, distribution, use, reuse, recycling, and final disposition.

To measure corporate carbon footprints (CCF), there have been numerous initiatives, guidelines and calculation methods that have emerged recently to quantify company-level direct and indirect greenhouse gas emissions. Most of them are based on the philosophy and classification of the Greenhouse Gas Protocol [29,30]:

- Scope 1: Direct emissions, sources possessed or controlled by the organization (e.g., emissions from own boilers, vehicles etc.)

- Scope 2: Indirect emissions related to electricity from the generation of purchased electricity consumed by the organization. (Furthermore, other types of purchased energy-such as steam or heat-can also be covered here.)

- Scope 3: Other indirect emissions in connection with activities such as external transportation or downstream phase of products (use, end-of-life etc.). Scope 3 is a voluntary accounting category that enables us to cover all other indirect emissions related to the carbon impacts embedded in the value chain. In addition to upstream emissions (indirect emissions along the supply chain from raw material extraction to the activity of the specific company), Lenzen and Murray [31] 
highlight the inclusion of downstream impacts (from the company to the end-of-life of the product including the product use phase, as well) in organizational carbon footprint accounts, too. Taking into account all these indirect emissions is usually a much bigger challenge when compared to Scopes 1 and 2.

There is a massive body of literature discussing the conceptual framework of corporate carbon footprinting $[32,33]$. Indeed, many companies and other organizations tend to measure, control and report their carbon emissions.

Validity and reliability issues of corporate level CF calculations are also important topics. In our previous research [34] we compared online corporate level carbon footprint calculators available free of charge for companies in this respect. We found that online corporate carbon calculators could be useful to provide the first insight for companies into their carbon footprints and they can also be useful for temporal comparisons at a certain company. However, these calculators did not prove to be appropriate for comparisons among different companies or to certain external benchmarks.

Using the CCF for a business can be beneficial in many different aspects, including:

- providing data for external and internal carbon reporting (delivering information for both final consumers and other stakeholders along the supply chain),

- as part of a carbon accounting system, pointing out inefficiencies can serve as a basis for interventions for cost savings,

- achieving synergies with other functional areas of the enterprise (for example, research and development (R\&D) for promoting greener and cleaner innovations, design for the environment),

- motivating employees as a climate-conscious enterprise,

- improving corporate image, etc.

Indeed, carbon footprinting can enable companies to integrate environmental aspects into other functional fields of the enterprises and to strengthen the link between environmental and economic goals. This process is an important step towards the direction that environmental protection and sustainability is not only an isolated area within a company anymore, but they should be integrated into other corporate fields as well (parallel to the spirit of the Goal on Climate Change of the UN Sustainable Development Goals, [11]). Figure 1 highlights some potential functional areas, where the application of the carbon footprint concept can support other functions.

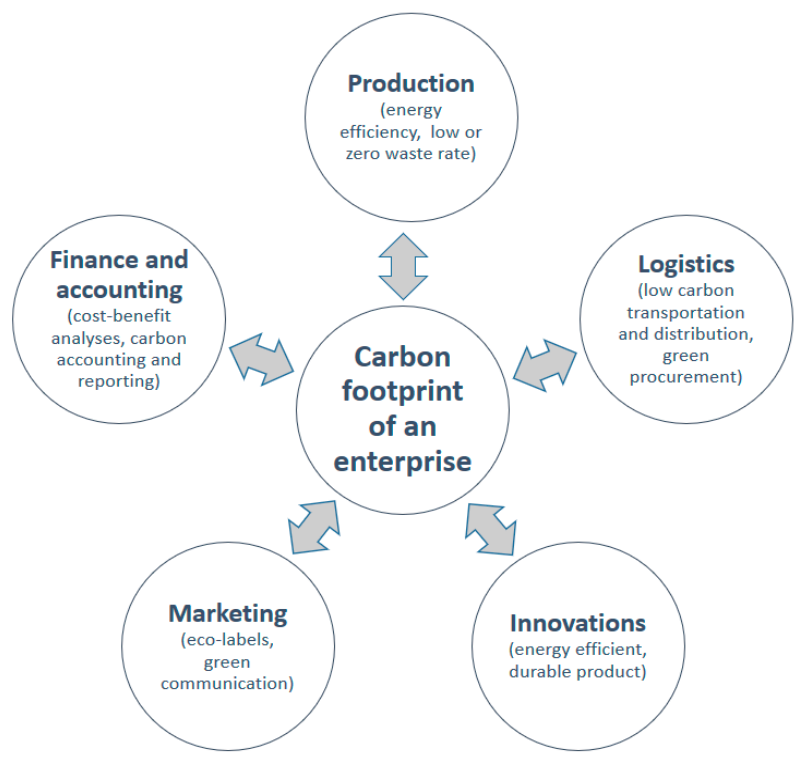

Figure 1. Relationship of corporate carbon footprinting to other organizational functional areas, source: [35]. 
Stein and Khare [36] proved that in most of the cases, indirect emissions (not including direct emissions from sources possessed or operated by the organization + electricity indirect GHG emissions based on the generation of power elsewhere used by the organization) account for the largest share of CCF. Based on a study among US companies, Matthews et al. [37] estimated the share of indirect emissions as much as $74 \%$ of the total CF. These emissions are related mostly to the extraction of raw materials, transportation and distribution both upstream and downstream of the supply chain, in the use phase and end-of-life treatment of products.

These factors naturally vary greatly among different industries. For instance, in beer production, according to Heineken's calculations, the company's carbon footprint includes massive shares of indirect factors, such as producing packaging materials (39\%), cooling the product before consumption $(21 \%)$, growing agricultural raw materials (9\%), etc. [35]. Another example is the hydrocarbon industry, where the use phase (burning the product by the consumers) may account for as much as $90 \%$ of the total carbon footprint [30]. In spite of their importance, indirect emissions tend to be disregarded by companies, probably due to their complexity and interference with the company's interests.

Over the last twenty years, the field of carbon accounting has evolved a lot and provided useful information for organizations for different purposes. Csutora and Harangozo [32] differentiated four subsequent phases of this evolution:

1. Environmental management accounting first emerged when interest towards organizational-level environmental costs (such as resource or waste management costs) arose in the 1990s.

2. Carbon accounting (direct emissions) appeared at the same time as regulatory and public attention to climate change and accounting, auditing, and reporting of company-level $\mathrm{CO}_{2}$ emissions arose.

3. Carbon accounting (with indirect emissions) supplemented the previous points as attention was focused on the transboundary impacts (covering a larger set of organizations) of entire supply chains.

4. Climate change accounting is developing right now, as the horizon is being widened from carbon accounting to climate accounting and the focus shifts from emission-related costs to climate adaptation cost at the company level as well (for instance in the form of higher insurance costs, higher resource prices etc.).

Company level EF and CF calculations are rare. For example, Best Foot Forward (BFF) is a leading sustainability consulting group specialized in carbon and ecological footprint calculations and aiming to foster the foundation of a low-carbon economy. In one study, BFF researchers quantified the ecological footprint of different Guinness Partnership employees (managers, technical leaders, distance working colleagues) [38]. Total footprints have been calculated as the sum of their individual and office footprints, influenced by business travels, electricity use, heating, office material consumption and waste, and food consumption. Results are diverse and vary significantly by the functional area in the organization. The size of EF can be cut by legal, company and individual responsibilities: major advances can only be realized through significantly improved cooperation. In this sense, corporate EF calculations could be important, but do not show sufficient contribution to a low-carbon, sustainable economy.

As this short overview suggests, CCF is usually addressed and calculated in mass units (thus following the logic of the second interpretation of CF in Section 2.1). In this paper, we go one step further and translate the carbon emissions of the case company into carbon uptake land as part of the EF concept. This can be the starting point for calculating the corporate level EF by adding other components, too.

\subsection{Methodology of EF and CCF Calculation in Practice-The Case of ENPRO}

ENPRO is a real company (providing electricity for a European capital city), but we have chosen to use a fictional name, as our research has a confidentiality clause. Some basic data are distorted in order not to allow for recognition. However, EF, CF, energy consumption etc. data are real. The current 
company was established in the early 1990s (and its predecessor at the end of the 19th century) and is now the local branch of a British-based multinational company. ENPRO is listed on the stock exchange, has 365 employees, its turnover was 650,000 Euro in 2015, with a profit rate of $7 \%$ (after tax). ENPRO has a sister company in the same country; at the (local) group level they directly employ 2400 people. The ENPRO Group provides electricity for 2 million private clients and 2500 companies. The residential market is an oligopolistic and highly regulated market by the state, while the corporate market is a highly competitive one.

ENPRO complies with the strict environmental regulation of the specific country and the European Union, additionally, it meets the contemporary high voluntary standards of environmental management, e.g., it is certified to ISO 14001 since 2004, and an Energy Management System according to ISO 50001.

The method of EF calculation, considering its limitations, is primarily suitable for planning and documenting a company's own development, while also helping the quantification of environmental improvement results. As a "common unit", the footprint would help to compare the effects of different measures, to quantify the level of improvement and to assess the effects of future strategies. A positive effect of EF calculations is that the accounting of resource consumption data is performed in a systematic approach and by that, cross-referencing, potential database errors/inconsistencies unnoticed before can be avoided or corrected. EF represents a common unit of measurement for the assessment of eco-efficient (profitable in both economic and environmental terms) investments and measures.

In order to determine the EF of ENPRO, three areas of the company's operation were considered for the years 2011 and 2015:

- the fuel consumption of the company's vehicles (machinery, passenger cars, maintenance vehicles),

- the energy consumption (power, heat and natural gas) and the physical area of properties,

- the energy consumption of ENPRO's own power transmission network, based on the data of substations.

Thus, ENPRO's EF calculation is mainly focused on its CCF (and the built-in footprint part) as is usually the case with corporate footprint calculations. However, we go beyond the ordinary approach (calculating CCF in mass units) and translate CCF into gha. Furthermore, the frame of calculations was confined to company boundaries: only those factors that were directly impacted by the company and related to energy consumption were taken into account. Therefore, the calculated value is an underestimation of the actual EF (also covering indirect impacts along the supply chain). For the core data of the calculation, corporate databases and expert estimates were used.

The EF calculations were based on the following steps. For the CCF part, Global Footprint Network's (GFN) methodology was applied, while $\mathrm{CO}_{2}$-equivalents were determined based on the DEFRA's (Department for Environment, Food and Rural Affairs in Great Britain, thus the ministry responsible for environmental affairs) database [39]. The (hypothetical) forest area required to neutralize the calculated $\mathrm{CO}_{2}$-emissions was calculated based on the carbon dataset of GFN's nation-specific database. With a mathematical formula:

$$
\mathrm{CCF}=\sum \mathrm{E}_{\mathrm{i}} \times \mathrm{CO}_{2}-\mathrm{eq}_{\mathrm{i}} \times \mathrm{FI}_{\mathrm{i}},
$$

where $\mathrm{E}$ stands for the energy used in different forms (electricity, heat, gas, petrol/diesel) in natural units $\left(\mathrm{kWh}, \mathrm{GJ}, \mathrm{m}^{3}, \mathrm{~L}\right), \mathrm{CO}_{2}$-eq means the equivalence factors converting per unit energy consumption to $\mathrm{CO}_{2}$-emissions (DEFRA database), while $\mathrm{FI}$ is the footprint intensity factor (converting $\mathrm{CO}_{2}$-releases into land area, its value is $0.255 \mathrm{gha} /$ ton of $\mathrm{CO}_{2}$ /year) based on the GFN database [40]. The FI already covers the previously mentioned equivalence factor (EQF). The calculation of the built-up land footprint was much simpler-the physical land area was multiplied by the built-up land EQF. 
This approach does not cover four other EF elements (farmland, grazing land, forest, fishing grounds), even though these are not really relevant for the direct EF of the company. However, these should also be covered if considering the indirect $\mathrm{EF}$ (including food consumption of employees, embedded EF of purchased goods, etc.). The fundamental objective of the calculation was to determine the size, structure, and trends of ENPRO's direct EF, in order to better understand how this information can be used to improve the sustainability performance of the company.

\section{Results and Discussion}

Based on the calculations, the following results were received for ENPRO for the period between 2011 and 2015.

Based on the data in Table 1 it can be seen that the major contributor of ENPRO's EF is the footprint related to properties, then the energy used/lost at the power network and finally the fuel consumption of vehicles.

Table 1. The structure of ENPRO's ecological footprint.

\begin{tabular}{cccccccc}
\hline Years & EF Property (gha) & EF Vehicle (gha) & EF Substation (gha) & EF Total (gha) & Property \% & Vehicle \% & Substation \% \\
\hline 2011 & 3548.2 & 905.26 & 1286.29 & 5694.49 & 62 & 16 & 23 \\
2012 & 3163.53 & 923.28 & 1780.54 & 5823.29 & 54 & 31 \\
2013 & 2910.73 & 902.83 & 1901.22 & 5669.52 & 51 & 16 \\
2014 & 2442.76 & 902.78 & 1900.09 & 5200.38 & 46 & 17 \\
2015 & 2609.57 & 923.02 & 1850.21 & 5337.54 & 48 & 17 & 37 \\
\hline
\end{tabular}

By further analyzing the fuel consumption EF (the vehicles and machines consumed predominantly diesel, so we used this as the basis of our calculation, Table 2), the following results can be revealed:

- During the years examined, neither the size nor the structure of EF resulting from fuel consumption changed significantly.

- EF resulting from vehicles was about 900 gha, of which the share of passenger cars was about $10 \%$ (90 gha). Cab riding added only 2 gha to this, which was a negligibly small part of EF.

- The maintenance $4 \times 4$ vehicle group's fuel consumption accounts for $50 \%$ of the EF.

- Related to the EF of fuel consumption per $\mathrm{km}$, as a future opportunity, electric vehicles can offer a $30-50 \%$ reduction. In this respect, there is another significance of applying EF calculation in corporate analysis, since we were able to create a common denominator for units (liters and $\mathrm{kWh}$ ) that could not be compared directly before.

- Another possibility to reduce fuel consumption EF may also be to reconsider the chances of using vehicles more sparingly.

Table 2. The ecological footprint of fuel consumption.

\begin{tabular}{|c|c|c|c|c|c|c|c|c|c|}
\hline Years & $\begin{array}{c}\text { EF Machinery } \\
\text { (gha) }\end{array}$ & $\begin{array}{c}\text { EF Cars } \\
\text { (gha) }\end{array}$ & $\begin{array}{l}\text { EF Mainte-Nance } \\
\text { Vehicles (gha) }\end{array}$ & $\begin{array}{c}\text { EF } 4 \times 4 \\
\text { Maintenance } \\
\text { Vehicles (gha) }\end{array}$ & $\begin{array}{c}\text { EF Total } \\
\text { Vehicle (gha) }\end{array}$ & $\begin{array}{c}\text { Machin } \\
\text { Ery \% }\end{array}$ & Cars \% & $\begin{array}{l}\text { Maintenance } \\
\text { Vehicles \% }\end{array}$ & $\begin{array}{c}4 \times 4 \\
\text { Maintenance } \\
\text { Vehicles \% }\end{array}$ \\
\hline 2011 & 146.54 & 95.60 & 216.18 & 446.94 & 905.26 & 16 & 11 & 24 & 49 \\
\hline 2012 & 137.87 & 95.37 & 222.75 & 467.29 & 923.28 & 15 & 10 & 24 & 51 \\
\hline 2013 & 118.79 & 93.50 & 216.70 & 473.84 & 902.83 & 13 & 10 & 24 & 52 \\
\hline 2014 & 125.76 & 86.08 & 218.66 & 472.29 & 902.78 & 14 & 10 & 24 & 52 \\
\hline 2015 & 121.58 & 88.87 & 218.07 & 494.50 & 923.02 & 13 & 10 & 24 & 54 \\
\hline
\end{tabular}

The biggest contributor to the overall EF was the EF of the properties (Table 3). We found that:

- The size of EF coming from the properties' energy consumption was 3500-2500 gha, which was the most significant part of the corporate footprint.

- During the years examined the structure ENPRO properties' energy consumption EF has changed only slightly because, in spite of decreases in electricity and gas use, the consumption of district heating has not changed. 
- The most important component of the properties' EF was the consumption of electricity (39-44\%).

- There were 12 priority properties that accounted for $64-74 \%$ of all properties' EF. In the future, it would be worth concentrating on measures intending to reduce EF in these properties.

- The built-up land footprint of ENPRO only accounts for a minimal share (a little more than 1\%) of the total property EF.

- To compensate for the per square meter EF of ENPRO property, an average of 200 square meters forest area was needed.

Table 3. The ecological footprint of properties.

\begin{tabular}{cccccccccc}
\hline Years & $\begin{array}{c}\text { EF Electricity } \\
\text { (gha) }\end{array}$ & $\begin{array}{c}\text { EF Gas } \\
\text { (gha) }\end{array}$ & $\begin{array}{c}\text { EF District } \\
\text { Heat (gha) }\end{array}$ & $\begin{array}{c}\text { EF Infra- } \\
\text { Structure (gha) }\end{array}$ & $\begin{array}{c}\text { Property } \\
\text { Total EF (gha) }\end{array}$ & Electricity \% & Gas \% & $\begin{array}{c}\text { District } \\
\text { Heat \% }\end{array}$ & Infra-Structure \% \\
\hline 2011 & 1553.95 & 1150.22 & 798.77 & 45.25 & 3548.2 & 44 & 32 & 23 & 1 \\
2012 & 1326.22 & 1026.4 & 766.86 & 45.25 & 3163.53 & 42 & 32 & 24 & 1 \\
2013 & 1196.30 & 935.45 & 733.72 & 45.25 & 2910.73 & 41 & 32 & 25 & 2 \\
2014 & 958.98 & 807.63 & 630.90 & 45.25 & 2442.76 & 39 & 33 & 26 & 2 \\
2015 & 1001.01 & 776.2 & 787.10 & 45.25 & 2609.57 & 38 & 30 & 30 & 2 \\
\hline
\end{tabular}

Determining the ecological footprint of the substations' own consumption was a complex task. This calculation, in principle, can be carried out based on the consumption data given in $\mathrm{kWh}$.

- The overall EF of substations varied between 1290 and 1900 gha.

- The weight of substations in the structure of the company's EF has increased (this can also be a sign of increasing network losses due to the declining overall condition of the power grid and may need improvements in the future).

- The ecological footprint is 46-58 times larger than the substations' physical area.

However, inaccurate and missing data caused problems during calculations (Table 4). Due to significant differences, data sets had to be corrected based on expert estimates, which should be considered when we evaluate the results. For two branches of the ENPRO Group, data needed to be corrected in cooperation with company experts in case of 7 and 11 substations respectively (for one or more years). Corrections were carried out in cases when:

- There was a lack of data at a given operating substation.

- There was at least an order of magnitude fluctuation in the consumption between years, which could not be justified by any technical or professional reasons.

Table 4. The corrected data sets of the two branches in the ENPRO group.

\begin{tabular}{ccccccc}
\hline Branches & Categories & $\mathbf{2 0 1 1}$ & $\mathbf{2 0 1 2}$ & $\mathbf{2 0 1 3}$ & $\mathbf{2 0 1 4}$ & $\mathbf{2 0 1 5}$ \\
\hline \multirow{3}{*}{ ENPRO 1 } & corrected data (kWh) & $5,266,855$ & $7,977,983$ & $8,596,979$ & $8,667,828$ & $8,785,837$ \\
& initial data sets (kWh) & $5,196,662$ & $7,267,332$ & $8,184,723$ & $8,289,621$ & $10,208,644$ \\
& Difference & $1 \%$ & $9 \%$ & $5 \%$ & $4 \%$ & $-16 \%$ \\
\hline \multirow{2}{*}{ ENPRO } & corrected data $(\mathrm{kWh})$ & $3,823,505$ & $4,605,318$ & $4,839,196$ & $4,760,376$ & $4,289,838$ \\
2 & initial data sets (kWh) & $3,359,458$ & $4,254,932$ & $4,379,829$ & $5,076,581$ & $4,317,579$ \\
& Difference & $12 \%$ & $8 \%$ & $9 \%$ & $-7 \%$ & $-1 \%$ \\
\hline
\end{tabular}

Based on the results and the EF calculation process, the findings can be further discussed. By comparing the results of the EF calculations to economic data (e.g., the amount of distributed electricity and the EF data of substations), eco-efficiency indicators can be developed, calculated and communicated in non-financial (CSR) reports. EF and cost reduction resulting from the reduction in energy consumption of the company can be shared with a wider audience in the form of pilot projects and can serve as a basis of further similar projects beyond the boundaries of the company. 
For fixing data issues (such as the ones that arose at the substations), a database management technology for filtering outlier data can be recommended. A detailed analysis of recognized outliers could highlight technological, measurement, data collection, data entry and/or data analysis errors. A solution for this could be the use of boxplot diagrams or cluster analysis.

As a point of further discussions, the extension of the scope of the EF calculation can also be considered. For example, sulfur-hexafluoride $\left(\mathrm{SF}_{6}\right)$ is a greenhouse gas, however, not covered by the GFN method. However, it has been used by the company as an insulation gas in a quantity of $\sim 84 \mathrm{~kg}$ per year (based on the corporate interviews). If the extreme high greenhouse gas potential of $\mathrm{SF}_{6}(22,800)$ is considered, based on our calculation method it accounts about 478 gha per year, a considerable land area compared to the current results. If the amount of $\mathrm{SF}_{6}$ would increase in the future, this could at least neutralize the achievements delivered by eco-efficient measures.

For covering the EF of non-carbon GHGs, the original assumption (calculating the forest area needed to neutralize the equivalent amount of this specific gas) may not work directly (as, for example, SF6 cannot be physically sequestered by forests). However, the method presented by Equation (1) can still be acceptable, as we assume that forests do not neutralize the same molecules (not even the same gas), but an equivalent amount of GHG in the form of $\mathrm{CO}_{2}$ (weighted by the EQFs, of course). If we accept that the biggest share of human-related GHG-emissions (considering also GWPs) is still $\mathrm{CO}_{2}$, then this assumption can be maintained.

This case study was similar to other CCF approaches in the sense that we mainly covered the energy-related CF of the ENPRO. However, we did not follow the ordinary CCF logic and presented the results in mass units (tons), but rather, transformed emissions to gha. This contributes to the development of the corporate EF framework. Additionally, we also covered the built-in EF component in gha. Furthermore, in the future, the scope of the EF calculation can be extended even more, while it could also cover the other components of EF. For example, the use of materials (e.g., paper) or food consumption could better serve as a benchmark and may contribute to environmentally conscious decisions of the managers and employees. On the whole, the extension of the scope could help the company to have a more proper view on its activity in terms of its EF and have a chance to consider a wider range of measures improving its performance.

The results of EF calculations can serve as a basis for measuring improving efficiency. The company has participated in the Money Back through the Window (MBtW) program [41] of the Hungarian Association for Sustainable Economies (KÖVET). In connection with this program, savings bringing both environmental and financial benefits have been identified. Within the program, so far 12 case study collections have been published, between 2002 and 2017, covering 534 projects from 99 organizations, with a unified methodology, aggregated results and prizes awarded, for each year. The savings can be classified into three groups:

(1) Washed fruits on a plate-with no investment, only reorganizational or behavior-change measures, in other words, zero payback period;

(2) Low-hanging fruits-Measures involving investments with a payback period of fewer than three years; and

(3) High-hanging fruits-Measures involving investments with a payback period of over 3 years.

Within the MBtW program, ENPRO applied with five different measures in recent years. A typical zero-investment measure (falling into category 1) based on the classification above, (i) a smart building management system, that controls gas consumption and heating based on the actual season, time of the day, external temperature. In addition to that, employee awareness has been raised by stickers and other easy-to-understand communication tools, in order to use less energy and water. Climate conditioners are centrally turned off at the end of the working day, and heating is kept at the minimal temperate mode at weekends. Efficiency has been further enhanced by the rationalization of the use of buildings. 
As "high-hanging fruits" four other measures have also been implemented by ENPRO. Major cuts of electricity use have been achieved by (ii) modernizing the lighting system of a sports court at the company, the lights of the alarm escape route in the central administration building, and the outdoor illumination of a third facility, through LED lights. (iii) In the secondary headquarters, a photovoltaic system was installed. Both centers were equipped with central air conditioning. (iv) Boilers of the primary headquarters were modernized, bringing substantial improvements in natural gas use. (v) Promoting electric vehicles have been a strategic priority for the company. As a supplier, ENPRO contributes to diminishing urban air pollution and the CF of transportation via building the infrastructure for charging electric vehicles. Now, this is in a pilot phase, but the demanded capacity is much higher than the current scale. As an organization, ENPRO makes efforts to increase the share of electric vehicles both for personal transport of its own staff and for commercial vehicles. Table 5 summarizes the major data of the measures from both environmental and financial perspectives.

Table 5. Environmental savings at ENPRO_-projects presented for the Money Back through the Window case study program [41].

\begin{tabular}{|c|c|c|c|}
\hline Measure, Project & Since & $\begin{array}{l}\text { Quantified Environmental } \\
\text { Benefit Per Annum }\end{array}$ & $\begin{array}{c}\text { \& Yearly Operational Cost } \\
\text { \& Yearly Savings } \\
\text { (1) Payback Period }\end{array}$ \\
\hline $\begin{array}{l}\text { (i) Smart building management system, } \\
\text { rationalization of building-use, } \\
\text { awareness raising of employees }\end{array}$ & 2011 & $\begin{array}{l}\text { Yearly mean resource saving: } \\
957 \mathrm{MWh} \text { of electricity } \\
110,600 \mathrm{~m}^{3} \text { of natural gas } \\
1438 \mathrm{GJ} \text { of district heating } \\
4300 \mathrm{~m}^{3} \text { of water used } \\
1700 \text { tons of } \mathrm{CO}_{2} \text { equivalent }\end{array}$ & 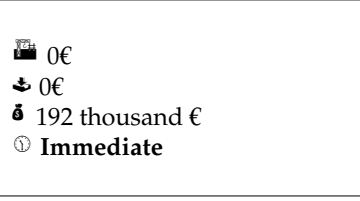 \\
\hline $\begin{array}{l}\text { (ii) Modernization of the lighting system, } \\
\text { change of indoor and outdoor lamps for } \\
\text { LED lights }\end{array}$ & 2015 & $\begin{array}{l}163 \mathrm{MWh} \text { of electricity } \\
92 \text { tons of } \mathrm{CO}_{2} \text { equivalent }\end{array}$ & $\begin{array}{l}\text { D. } 110 \text { thousand } € \\
\pm 0 € \\
\text { o } 20 \text { thousand } € \\
\text { (1) years and } 6 \text { months }\end{array}$ \\
\hline $\begin{array}{l}\text { (iii) Central air conditioning of two } \\
\text { central buildings, installing a } \\
\text { photovoltaic system }\end{array}$ & 2013 & $\begin{array}{l}137 \mathrm{MWh} \text { of electricity } \\
78 \text { tons of } \mathrm{CO}_{2} \text { equivalent }\end{array}$ & 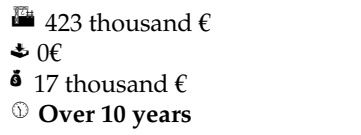 \\
\hline $\begin{array}{l}\text { (iv) Modernization of boilers and smart } \\
\text { control of office temperature }\end{array}$ & 2014 & $\begin{array}{l}35,410 \mathrm{~m}^{3} \text { of natural gas } \\
107 \text { tons of } \mathrm{CO}_{2} \text { equivalent }\end{array}$ & $\begin{array}{l}\text { [- } 123 \text { thousand } € \\
\pm 0 € \\
\text { o } 12 \text { thousand } € \\
\text { 10 years }\end{array}$ \\
\hline $\begin{array}{l}\text { (v) Purchase and operation of electric } \\
\text { vehicles }\end{array}$ & 2011-2012 & $\begin{array}{l}1700 \mathrm{~L} \text { of fuel } \\
3.3 \text { tons of } \mathrm{CO}_{2} \text { equivalent }\end{array}$ & $\begin{array}{l}\text { Dit } 87 \text { thousand } € \\
\pm 0 € \\
\text { ஃ } 2 \text { thousand } € \\
\text { Over } 10 \text { years }\end{array}$ \\
\hline
\end{tabular}

Source: calculation of the authors based on a consulting project [41].

Based on the data, it can be seen that these projects (partly initiated by the high EF values) can deliver both environmental and economic benefits for the companies, even if the payback time is a somewhat lengthy in some of these specific cases.

ENPRO has significantly improved its eco-efficiency in the recent years, as it is obvious from Table 6.

According to Table 6, the company has made a series of investments, rationalization and other reorganizational measures in its buildings and operational plants. In five years, these resulted in a net saving of almost one million euro, equivalent to 7900 tons of carbon-dioxide. If these results are converted to EF values based on the method presented earlier, it means a 500 gha EF saving per annum or $14 \%$ EF decrease from 2011 to 2016 . The consistent plan for eco-efficiency improvements is far from being over: another $10 \%$ EF reduction is foreseen in the next period ending in 2026. 
Table 6. Eco-efficiency measures of ENPRO, related to real estate management, between 2011-2016.

\begin{tabular}{ccccc}
\hline & $\begin{array}{c}\text { Saving from } \\
\text { Electricity }\end{array}$ & $\begin{array}{c}\text { Savings from } \\
\text { Natural Gas }\end{array}$ & $\begin{array}{c}\text { Savings from } \\
\text { District Heating }\end{array}$ & Total Savings \\
\hline $\begin{array}{c}\text { Saving compared to 2011 } \\
\text { (in natural units) }\end{array}$ & $6112 \mathrm{MWh}$ & $510,732 \mathrm{~m}^{3}$ & $5752 \mathrm{GJ}$ & - \\
\hline $\begin{array}{c}\text { Saving compared to } 2011 \\
\text { (thousand } € \text { ) }\end{array}$ & 670 & 190 & 87 & 947 \\
\hline Saving in $\mathrm{CO}_{2}$ equivalent (tons) & 3460 & 3075 & 1365 & 7900 \\
\hline Source: own calculations based on a consulting project.
\end{tabular}

\section{Conclusions}

In 2018, it is widely accepted both in the scientific community and general public that our progress cannot be one dimensional, and sustainable development needs harmonized progress in economics, social advances, and ecological balance. There is a growing demand from the society that social and natural sciences should provide composite indicators. GDP and other one-dimensional economic indicators will still have their roles in the future, but we will also need two or three-dimensional indicators. The triple-bottom-line approach [42] is widely used in the corporate world and academic teaching. In this paper, we proposed that the EF can be used related to at least two dimensions (the environmental and the economic) of sustainable development. It can also be considered as an eco-efficiency indicator that informs economic - but not only economic-strategies and decisions, primarily as a long-term resource planning tool [43,44]. A social dimension might come under the loop if an equality of distribution of natural and economic wealth would play a role in the future, which we foresee but cannot forecast from our present data.

At the beginning of the paper, EF was approached from a macro perspective. It was considered as a sustainability indicator at the macro level and was compared to other mainstream (GDP) and alternative indicators. Based on this it was highlighted that EF is not only an environmental indicator but can supplement (or even compete with) other complex indicators of sustainability and development.

After that, EF was decomposed and an important element, namely $\mathrm{CF}$, was highlighted. $\mathrm{CF}$ is a key contributor to the company level EF accounts (CCF). We argued that translating ordinary CCF accounts (measured in mass units) into CF measured in land units can be the first step towards extending and developing a framework towards an assessment of corporate level EF. After covering some methodological aspects of EF calculation, a company level EF calculation case was presented and analyzed. Based on the ENPRO case, it was found that ecological and carbon footprinting can serve as powerful tools in:

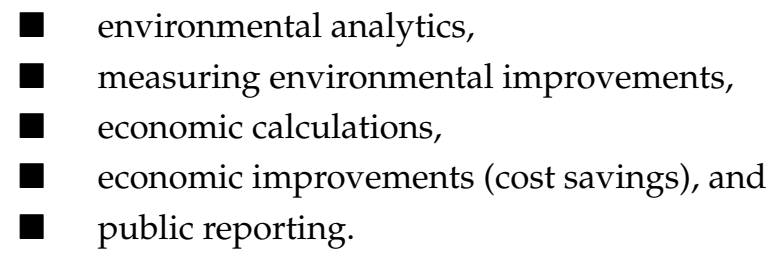

The link between EF calculations and such projects aiming to improve eco-efficiency is twofold. On the one hand, EF calculations can point out inefficiencies and emission hotspots, where certain measures are needed. On the other hand, EF calculations can be also applied to evaluate the results of such measures after their realization.

This efficiency of EF comes from two angles. The first is that we have a common tool to address both environmental and economic issues at the company level, and by that, a practical tool to improve eco-efficiency. The second is that common measurement units and wide awareness, plus an acceptance from the general public makes the EF and the CCF powerful tools for measurement and communication, despite their slight methodological flaws. 
By reaching beyond using it as a powerful indicator we are intending to integrate EF into a broader framework. We are convinced that mankind is in the so-called bifurcation zone, where sticking to the old patterns of accelerated growth (driven mainly by the wealth and consumption, not by the population anymore) might lead to a catastrophe or collapse, but it is also possible to tread on the path of a calmer, more balanced development, by localizing the world economy, which would offer us a positive alternative portrayed by a sigmoid curve. We need an economic paradigm change to find the positive (yellow) way out from the bifurcation zone and using the ecological and carbon footprint as sustainability indicators at both macro- and micro-scales plays a vital part here; this is what we can call the economics of enough, in contrast to the economics of more, and in scientific terms, human economics.

Author Contributions: Conceptualization, G.H.; Investigation, C.S.; Methodology, C.S.; Project administration, G.T. and D.R.S.; Validation, G.H.; Writing—original draft, G.T.

Funding: This research has been supported by the Hungarian National Research, Development and Innovation Office, from the NKFI Fund (K-120044 and K-116472).

Acknowledgments: This research has been supported by the Hungarian National Research, Development and Innovation Office, from the NKFI Fund (K-120044 and K-116472).

Conflicts of Interest: The authors declare no conflict of interest.

\section{References}

1. Wackernagel, M.; Rees, W. Our Ecological Footprint-Reducing Human Impact on the Earth; New Society Publisher: Gabriola Island, BC, Canada, 1996.

2. Rees, W.E. Ecological footprints and appropriated carrying capacity: What urban economics leave out. Environ. Urban. 1992, 4, 120-130. [CrossRef]

3. Wackernagel, M.; Onisto, L.; Bello, P.; Linares, A.C.; Falfán, I.S.L.; Garcia, J.M.; Guerrero, M.G.S. National natural capital accounting with the ecological footprint concept. Ecol. Econ. 1999, 29, 375-390. [CrossRef]

4. Stiglitz, J.E.; Sen, A.; Fitoussi, J.-P. Report by the Commission on the Measurement of Economic Performance and Social Progress. 2009. Available online: http:/ /ec.europa.eu/eurostat/documents/118025/118123/ Fitoussi+Commission+report (accessed on 31 July 2018).

5. Global Footprint Network. Footprint Basics-Overview. Global Footprint Network, 2012. Available online: www.footprintnetwork.org (accessed on 19 April 2018).

6. World Wildlife Fund (WWF). Living Planet Report; WWF: Gland, Switzerland, 2016.

7. Tóth, G.; Szigeti, C. The historical ecological footprint: From over-population to over-consumption. Ecol. Indic. 2016, 60, 283-291. [CrossRef]

8. Vackár, D. Ecological Footprint, environmental performance and biodiversity: A cross-national comparison. Ecol. Indic. 2012, 16, 40-46. [CrossRef]

9. York, R.; Rosa, E.A.; Dietz, T. The ecological footprint intensity of national economies. J. Ind. Ecol. 2004, 4, 139-154. [CrossRef]

10. Szigeti, C.; Tóth, G.; Borzán, A.; Farkas, S. GDP Alternatives and their Correlations. J. Environ. Sustain. 2013, 3, 35-46. [CrossRef]

11. United Nations. Transforming Our World: The 2030 Agenda for Sustainable Development; UN Sustainable Development Summit: New York, NY, USA, 2015.

12. Organisation for Economic Co-operation and Development (OECD). Towards Green Growth; OECD: Paris, France, 2011.

13. Urhammer, E.; Røpke, I. Macroeconomic narratives in a world of crises: An analysis of stories about solving the system crisis. Ecol. Econ. 2013, 96, 62-70. [CrossRef]

14. Wiedmann, T.; Minx, J. A definition of 'carbon footprint'. Ecol. Econ. Res. Trends 2008, 1, 1-11.

15. Galli, A.; Wiedmann, T.; Ercin, E.; Knoblauch, D.; Ewing, B.; Giljum, S. Integrating ecological, carbon and water footprint into a "footprint family" of indicators: Definition and role in tracking human pressure on the planet. Ecol. Indic. 2012, 16, 100-112. [CrossRef]

16. Csutora, M. Az ökológiai lábnyom számításának módszertani alapjai. In Az Ökológiai Lábnyom Ökonómiája: Tematikus Kötet; Mária, C., Ed.; Aula Kiadó: Budapest, Hungary, 2011; pp. 6-15. 
17. Mancini, M.S.; Galli, A.; Niccolucci, V.; Lin, D.; Bastianoni, S.; Wackernagel, M.; Marchettini, N. Ecological footprint: Refining the carbon footprint calculation. Ecol. Indic. 2016, 61, 390-403. [CrossRef]

18. Wiedmann, T.O.; Lenzen, M.; Barrett, J.R. Companies on the scale comparing and benchmarking the sustainability performance of businesses. J. Ind. Ecol. 2009, 13, 361-383. [CrossRef]

19. Song, G.; Che, L.; Zhang, S. Carbon footprint of a scientific publication: A case study at Dalian University of Technology, China. Ecol. Ind. 2016, 60, 275-282. [CrossRef]

20. Johnson, E. Carbon footprints of heating oil and LPG heating systems. Environ. Impact Assess. Rev. 2012, 35, 11-22. [CrossRef]

21. Johnson, E.; Tschudi, D. Baseline effects on carbon footprints of biofuels: The case of wood. Environ. Impact Assess. Rev. 2012, 37, 12-17. [CrossRef]

22. Fang, K.; Heijungs, R.; Snoo, G.R. Theoretical exploration for the combination of the ecological, energy, carbon, and water footprints: Overview of a footprint family Ecol. Indic. 2014, 36, 508-518. [CrossRef]

23. Kim, B.; Neff, R. Measurement and communication of greenhouse gas emissions from US food consumption via carbon calculators. Ecol. Econ. 2009, 69, 186-196. [CrossRef]

24. Downie, J.; Stubbs, W. Evaluation of Australian companies' Scope 3 greenhouse gas emissions assessments. J. Clean. Prod. 2013, 56, 156-163. [CrossRef]

25. Herva, M.; Franco, A.; Carrasco, E.; Roca, E. Review of corporate environmental indicators. J. Clean. Prod. 2011, 19, 1687-1699. [CrossRef]

26. Bagliani, M.; Martini, F. A joint implementation of ecological footprint methodology and cost accounting techniques for measuring environmental pressures at the company level. Ecol. Indic. 2012, 16, 148-156. [CrossRef]

27. Vázquez-Rowe, I.; Villanueva-Rey, P.; Mallo, J.; De la Cerda, J.; Moreira, T.; Feijoo, G. Carbon footprint of a multi-ingredient seafood product from a business-to-business perspective. J. Clean. Prod. 2013, 44, 200-210. [CrossRef]

28. Penela, A.C.; García-Negro, M.C.; Quesada, J.L.D. A methodological proposal for corporate carbon footprint and its application to a wine-producing company in Galicia, Spain. Sustainability 2009, 1, 302-318. [CrossRef]

29. WBCSD, WRI. The Greenhouse Gas Protocol-A Corporate Accounting and Reporting Standard; World Business Council for Sustainable Development and World Resources Institute: Geneva, Switzerland, 2004; p. 116.

30. WBCSD, WRI. The Greenhouse Gas Protocol_Corporate Value Chain (Scope 3) Accounting and Reporting Standard. Supplement to the GHG Protocol Corporate Accounting and Reporting Standard; World Business Council for Sustainable Development and World Resources Institute: Geneva, Switzerland, 2011; p. 152.

31. Lenzen, M.; Murray, J. Conceptualising Environmental Responsibility. Ecol. Econ. 2010, 70, $261-270$. [CrossRef]

32. Csutora, M.; Harangozó, G. Twenty years of carbon accounting and auditing. Soc. Econ. 2017, 39, 459-480.

33. Schaltegger, S.; Csutora, M. Carbon accounting for sustainability and Management. Status quo and challenges. J. Clean. Prod. 2012, 36,1-16. [CrossRef]

34. Harangozó, G.; Szigeti, C. Corporate carbon footprint analysis in practice-With a special focus on validity and reliability issues. J. Clean. Prod. 2017, 167, 1177-1183. [CrossRef]

35. Heineken. Heineken Holding N.V. 2015 Sustainability Report. Available online: http://www. theheinekencompany.com/sustainability/focus-areas/reducing-co2-emissions (accessed on 2 March 2017).

36. Stein, M.; Khare, A. Calculating the carbon footprint of a chemical plant: A case study of Akzonobel. J. Environ. Assess. Policy Manag. 2009, 11, 291-310. [CrossRef]

37. Matthews, H.S.; Hendrickson, C.T.; Weber, C.L. The importance of carbon footprint estimation boundaries. Environ. Sci. Technol. 2008, 42, 5839-5842. [CrossRef] [PubMed]

38. BFF (Best Foot Forward). A Carbon Footprint Analysis of Three GUINNESS Partnership Employees; The Guinness Partnership: London, UK, 2007.

39. DEFRA-Department of Environment Food \& Rural Affairs. UK Government Conversion Factors for Company Reporting. 2013. Available online: http://www.ukconversionfactorscarbonsmart.co.uk (accessed on 5 February 2017).

40. Global Footprint Network. National Footprint Accounts, 2015 ed.; Global Footprint Network: Budapest, Hungary, 2017. 
41. Herner, K.; Szám, D.; Tóth, G. Money Back through the Window XII-Ten Case Studies on Measures Bringing both Environmental and Economic Benefits. KÖVET: Budapest, 2017; p. 28. Available online: http:/ / ec.europa.eu/environment/archives/sme/cases/article_9099_en.htmafull-textdatabase (accessed on 20 July 2018).

42. Elkington, J. Cannibals with Forks: The Triple Bottom Line of 21st Century Business; Capstone: Oxford, UK, 1997.

43. Daly, H.E. On Nicholas Georgescu-Roegen's contribution to economics: An obituary essay. Ecol. Econ. 1995, 13, 149-154. [CrossRef]

44. Schumacher, E.F. Small is Beautiful-A Study of Economics as if People Mattered; Blond \& Briggs: London, UK, 1973.

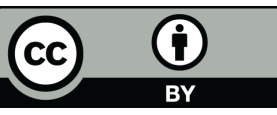

(C) 2018 by the authors. Licensee MDPI, Basel, Switzerland. This article is an open access article distributed under the terms and conditions of the Creative Commons Attribution (CC BY) license (http://creativecommons.org/licenses/by/4.0/). 